Egyptian Poultry Science Journal

http://www.epsaegypt.com

ISSN: 1110-5623 (Print) - 2090-0570 (On line)

\title{
PRODUCTIVE PERFORMANCE AND IMMUNE RESPONSE OF BROILER CHICKS AS AFFECTED BY DIETARY MARJORAM LEAVES POWDER
}

\author{
A. H. H. Ali, \\ Anim. and poult. Prod. Dep., Fac. of Agric., South Valley Univ., Qena, Egypt
}

Received: $16 / 01 / 2014$

Accepted: 02/02/2014

\begin{abstract}
Ninety six unsexed one-day old, Ross 308 broiler chicks, were randomly divided into 4 treatment groups. Each treatment had 3 replicates with 8 chicks each. The chicks of each replicate were allocated in a cage. The basal experimental diets had 24 and $22 \%$ crude protein and 3009 and $3135 \mathrm{Kcal} \mathrm{ME} / \mathrm{kg}$ diet for the starter and the grower diet, respectively. The experiment was included four treatments, treatment 1 ; chicks were fed on basal diet without any addition (control). Whereas, in treatments 2, 3 and 4 chicks were received $0.5 \%, 1.0 \%$ and $1.5 \%$ marjoram leaves powder (Origonum marjorana), respectively.

Supplementing the broiler diet with marjoram leaves powder increased significantly $(\mathrm{P}<0.05)$ Live body weight $(\mathrm{BW})$ at 21 and 42 days of age, daily body weight gain (BWG) at all periods and globulin than the control group. Moreover, addition of marjoram improved $(\mathrm{P}<0.05)$ feed conversion ratio $(\mathrm{FCR})$ at all periods and decreased significantly $(\mathrm{P}<0.05)$ daily feed intake $(\mathrm{FI})$ at 4-6 and 0-6 weeks of age, albumin and albumin/ globulin ratio in the treated groups as compared with control group. Conversely, supplementing the broiler diets with marjoram leaves powder had no significant effect on feed intake (FI) at 0 3 weeks of age, hematocrit HCT, hemoglobin, glucose, total protein, cholesterol, LDL cholesterol, HDL cholesterol, heterophils (H), lymphocytes (L), monocytes, H/L ratio, averages of serum haemagglutinin antibody (Ab.) titers against SRBC's at 6 weeks of age and spleen and bursa percentages. Overall, these data indicate that, supplementing marjoram into the broiler diets improved productive performance but it did not affect the immune response.
\end{abstract}

Key Words: Marjoram leaves, immune response, productive performance.

Corresponding author: attai73@yahoo.com 


\section{INTRODUCTION}

Antibiotic feed additives have long been used as growth promoters in poultry nutrition. However, concern has been expressed about the potential development of antibiotic resistant bacteria (Sarica et al., 2005). Consequently, the animal feed industry, exposed to increasing consumer pressure to reduce the use of antibiotic growth promoters (AGPs) in poultry diets, has to find alternative feed additives (Humphrey et al., 2002; Botsoglou et al., 2004). Herbs could be used as alternatives to AGPs in poultry nutrition due to their antimicrobial properties. Many herbs and their bio-active constituents possess a broad antimicrobial activity (Dorman and Deans, 2000; Kamel, 2001; Tucker, 2002; Cross et al., 2003; Lewis et al., 2003). Scientific evidence exist that herbs and plant extracts stimulate the growth of beneficial bacteria and minimize pathogenic bacterial activity in the gastrointestinal tract of poultry (Gill, 1999; Langhout, 2000; Wenk, 2000).

The genus Origanum majorana L. is an aromatic, perennial, herbaceous plant belonging to the family Lamiaceae. The plant has been used as a flavoring and herbal spice from time immemorial. Steam distillation of leaves and flower heads yields a volatile oil, known in the trade as oil of Sweet marjoram, widely used in flavoring food and also in perfumery. Medicinally it is used in both Ayurveda and Yunani system to cure various human ailments Leeja and Thoppil, (2007). Marjoram (Origonum marjorana) is a very popular and a common medicinal plant Ezz El-Arab (2008). It contains about 0.5-3\% oil. The main chemical composition of marjoram oil is Borneol, Terpinene, Pinene, Sabinene and Terpineol (Banchio et al., 2008). The plant is pungent, bitter, hot, stomachic, anthelmintic, useful in diseases of the heart and blood, fevers and inflammation (Kirtikar and Basu, 1985). An infusion of the plant is used as a stimulant, sudorific and also useful in asthma, hysteria and paralysis (Farooqi and Sreeramu, 2004). The plant is reported to possess antibacterial activity (Ben et al., 2001; Farooqi and Sreeramu, 2004).

The present study was carried out to investigate the effect of adding different levels of marjoram leaves powder into broiler diets on the productive performance and immune response of broiler chicks.

\section{MATERIALS AND METHODS}

This study was carried out at the Poultry Farm, Department of Animal and Poultry Production, Faculty of Agriculture, South Valley University, Qena. It was designed to evaluate the effects of adding different levels of marjoram leaves powder (Origonum Marjorana) into broiler diets on the productive performance (body weight, daily gain, feed intake and feed conversion) and immune responses of broiler chicks.

\section{Chicks and Housing:}

Ninety six unsexed one-day old; Ross 308 broiler chicks were obtained from a commercial local source and used in this study. Chicks were randomly divided into 4 treatment groups. Each treatment had 3 replicates with 8 chicks each (4 treatments X 3 replicates $X 8$ chicks $=96$ chicks). Chicks in each replicate within each treatment had nearly similar initial live body weight $(50 \pm 2 \mathrm{gm})$. Chicks were reared in two-tier wire floor battery in a windowless house including ventilation systems and heater that functions as needed, most often with micro-processor controls. The chicks of each replicate were allocated in a cage with slatted floor of iron.

\section{Diets and management:}

The experimental period was divided into two feeding phases, starter (from 0-3 weeks of age) and grower (from 4-6 weeks of age). The basal experimental diets had 24 and $22 \%$ crude protein and 
3009 and $3135 \mathrm{Kcal} \mathrm{ME} / \mathrm{kg}$ diet for the starter and the grower diet, respectively (Table 1). Experimental diets were formulated to meet the nutrients requirements of the broiler chicks (National Research Council, NRC, 1998).

Chicks have full access to feed and water during the experimental period. Artificial light was applied to maintain 23 hrs. light per day during the experimental period. The environmental temperature was about $32^{\circ} \mathrm{C}$ during the first week old and it was gradually reduced by about $2^{\circ} \mathrm{C}$ weekly until about $24^{\circ} \mathrm{C}$ at the fourth week up to the end of experiment (at 6 weeks of age).

The experiment was included four treatments, treatment 1 ; chicks were fed on basal diet without any addition (control). Whereas, in treatments 2,3 and 4 chicks were received $0.5 \%, 1.0 \%$ and $1.5 \%$ marjoram (Origonum Marjorana) leaves powder, respectively. Chemical composition of marjoram leaves is presented in Table (2).

Table (1): Composition of the starter and grower basal diets.

\begin{tabular}{|l|l|l|}
\hline \multicolumn{1}{|c|}{ Ingredients } & \multicolumn{1}{c|}{ Starter } & Grower \\
\hline Yellow corn & 52.59 & 56.04 \\
Soybean meal (44\% CP) & 32 & 30 \\
Corn gluten (60\% CP) & 9 & 6 \\
Vegetable oil & 2 & 4 \\
Premix* & 0.3 & 0.3 \\
Dicalcium phosphate & 2 & 1.8 \\
Limestone & 1 & 1 \\
Lysine & 0.3 & 0.2 \\
Methionine & 0.25 & 0.125 \\
Choline chloride & 0.2 & 0.175 \\
Salt & 0.36 & 0.36 \\
Total & 100 & 100 \\
\hline Calculated values & 24 & 22 \\
\hline Crude protein \% & 3009 & 3135 \\
ME (Kcal/kg) & 0.91 & 0.86 \\
Calcium \% & 0.48 & 0.43 \\
Av. Phosphorus \% & 0.74 & 0.55 \\
Methionine & 1.45 & 1.27 \\
Lysine \% & *Vitamins and minerals premix provided per kilogram of the diet: Vit A, 1000 IU; D3 \\
2000 ICU; Vit E, 10 mg; Vit K, 1mg; B1, 10 mg; B2, 5 mg; B6, 1500 mg; B12, 10mg \\
Pantothenic acid, 10 mg; Nicotinic acid, 30 mg; Folic acid, 1mg; Biotin, 50 mcg; \\
Chloride, 500 mg; copper, 10 mg; iron, 50 mg; Manganese, 60 mg; Zinc, 50mg, and \\
selenium, 0.1 mg.
\end{tabular}


Table (2): Chemical composition of marjoram leaves powder based on dry matter

\begin{tabular}{|c|c|}
\hline $\begin{array}{ll}\text { Chemical composition } \% & \text { Ingredient } \\
\end{array}$ & Marjoram \\
\hline Moisture & 7.25 \\
\hline Protein & 12.05 \\
\hline Fat & 2.98 \\
\hline Ash & 9.88 \\
\hline Fiber & 16.44 \\
\hline NFE (nitrogen free extract) & 51.40 \\
\hline Total & 100 \\
\hline
\end{tabular}

\section{Hygiene:}

Chicks were vaccinated against Newcastle disease three times, firstly with Hitchner B1 on the 7th day of age and twice with Lasota strain in drinking water at 12 and 24 days of age. At 14 and 28 days of age, chicks were vaccinated against infectious bursal disease (Gumboro).

\section{Productive performance:}

Live body weight and feed intake were recorded at 3 and 6 weeks of age (two periods) for each replicate. Daily body weight gain and feed conversion ratio (gm feed: gm gain) were calculated for each replicate within each period.

There was not any died chick at whole experimental period from any treated group or control group.

\section{Physiological measurements:}

Fresh blood samples, each of $2 \mathrm{ml}$, were collected from six chicks (chosen randomly) within each treatment at 5 and 6 weeks of age in heparinized tubes. However, blood samples were betided every time between 8:00 to 8:30 am. The blood samples were collected to determine hematological parameter, hemoglobin $(\mathrm{Hb})$ concentration using hemometer as the method described by Tietz (1982), hematocrit (HCT) according to Winderobe (1967).Two drops of blood from each sample were smeared on two glass slides. The smears were stained within 2 to $3 \mathrm{hrs}$. of preparation using May-Gunwale, Giemsa Stains. One hundred leukocytes, including heterophils (H), lymphocytes (L), basophils, eosinophils and monocytes were counted on each slide and $\mathrm{H} / \mathrm{L}$ ratio was calculated by dividing the number of heterophils by that of lymphocytes as described by Sturkie (1986). Both slides were counted and the mean $\mathrm{H} / \mathrm{L}$ ratio was calculated for each chick.

At 5 weeks of age, six chicks from each treatment were injected intravenously in the brachial vein with $0.2 \mathrm{ml}$ of $10 \%$ suspension of packed sheep red blood cells (SRBC's). Sera were collected on the seventh day post immunization (at 6 weeks of age) and antibody titer against SRBC's was determined using the micro titer procedure described by Van der Zijpp and Leenstra (1980). Titers were expressed as the $\log _{2}$ of the reciprocal of highest dilution giving complete agglutination. Serum total protein and albumin were determined according to Doumas, (1971); Witt and Trendelenburg (1982). Globulin concentration was calculated as the difference between total protein and albumin, then the ratio of albumin/globulin was also calculated. Total cholesterol was determined according to (Watson, 1960) and HDL Warnick (1983), LDL Assmann 
et al. (1984). Additionally, Plasma Glucose was determined according to the procedure of Coles, (1986).

At 6weeks of age six chicks (within average weight of treatment) from each treatment groups were slaughtered for estimation weights and percentages of spleen and bursa from live body weight.

\section{Statistical Analysis:}

Data collected were statistically analyzed by the analysis of variance with the General Linear Model (GLM) procedure of the SAS Institute (SAS, 1996). All statements of significance are based on the 0.05 level of probability. Significant differences among treatments were performed using Duncan's multiple range test (Duncan, 1955).

\section{RESULTS AND DISCUSSION}

\section{Body weight and daily gain:}

Data of body weight at 21 and 42 days of age are listed in Table (3). Data showed that all treated groups were significantly $(\mathrm{P}<0.05)$ heavier in body weight at 21 days of age than the control group. Moreover, supplementing the broiler diet with marjoram leaves powder had significant $(\mathrm{P}<0.05)$ effect on body weight at 42 days of age being the heaviest in the supplemented groups with 1 and $1.5 \%$ marjoram and lowest one was the control group even from supplemented group with $0.5 \%$ marjoram. The results are in agreement with Ezz El-Arab, (2008) and Mona Osman et al. (2010) who noted that, at 28 and 42 days of age chicks fed either rosemary, marjoram or sweet basil containing basal diets at the upper level $(1 \mathrm{~g} / \mathrm{kg})$ had a higher body weight means than those received the same studied feed additives at the lower level of $0.5 \mathrm{~g} / \mathrm{kg}$. Also, treatment of Marjoram $(1 \mathrm{~g} / \mathrm{kg})$ supplementation during growth periods of 42 days old gave the best score when compared with the corresponding treatments by an increment of 14.88, 5.23 and $2.42 \%$ over those of the control, Rosemary and Sweet Basil, respectively.

Obtained data of daily body weight gain at 0-3, 4-6 and 0-6 weeks of age in Table (3) indicated that treatment with marjoram increased $(\mathrm{P}<0.05)$ daily body weight gain during all periods than the control group. Also, supplemented groups with 1.0 and $1.5 \%$ marjoram achieved the greatest body weight gain during 4-6 and 06 weeks of age. The results are in agreement with Ezz El-Arab, (2008) and Mona Osman et al. (2010). This may be due to the ability of marjoram to increase the efficiency of digestion by increasing digestive enzymes and saliva, calming the stomach and digestive system, improving appetite, curing or preventing basic intestinal infections and relieving diarrhea and constipation. This is in agreement with those mentioned by Hallnet, (2014). Ezz El-Arab, (2008) mentioned that, ability of natural feed additives to enhance broiler's appetite, is due to the fact that it is rich in a wide variety of secondary metabolites, such as, trepenoids, which have been found to have antimicrobial properties (Cowan, 1999), and antioxidant activity (Triantaphyhou et al., 2001), which in turn improves the lower gut health, bacterial population, improves nutrients absorption, utilization and eventually improves bird's health and increases body weight and weight gain. 
Table (3): Averages $\pm(\mathrm{SE})$ of body weight (gm) and daily body weight gain (gm) as affected by the addition of marjoram leaves powder into broiler chick diets.

\begin{tabular}{|c|c|c|c|c|c|}
\hline \multirow{2}{*}{ Items } & \multicolumn{2}{|c|}{ Body weight $(\mathbf{g m})$} & \multicolumn{3}{c|}{ Daily body weight gain $(\mathbf{g m})$} \\
\cline { 2 - 6 } Treat. & $\mathbf{2 1}$ days & $\mathbf{4 2 ~ d a y s}$ & $\mathbf{0 - 3}$ weeks & $\mathbf{4 - 6}$ weeks & $\mathbf{0}-\mathbf{6}$ weeks \\
\hline $\mathbf{0}$ & $810.4 \pm 5.51^{\mathrm{b}}$ & $2320.4 \pm 5.61^{\mathrm{c}}$ & $36.2 \pm 0.26^{\mathrm{b}}$ & $71.9 \pm 0.51^{\mathrm{c}}$ & $54.1 \pm 0.13^{\mathrm{c}}$ \\
$\mathbf{0 . 5}$ & $839.6 \pm 5.51^{\mathrm{a}}$ & $2460.4 \pm 9.08^{\mathrm{b}}$ & $37.6 \pm 0.26^{\mathrm{a}}$ & $77.2 \pm 0.19^{\mathrm{b}}$ & $57.4 \pm 0.22^{\mathrm{b}}$ \\
$\mathbf{1 . 0}$ & $849.2 \pm 4.35^{\mathrm{a}}$ & $2516.7 \pm 11.02^{\mathrm{a}}$ & $38.1 \pm 0.21^{\mathrm{a}}$ & $79.4 \pm 0.33^{\mathrm{a}}$ & $58.7 \pm 0.26^{\mathrm{a}}$ \\
$\mathbf{1 . 5}$ & $852.1 \pm 2.08^{\mathrm{a}}$ & $2511.7 \pm 12.94^{\mathrm{a}}$ & $38.2 \pm 0.10^{\mathrm{a}}$ & $79.0 \pm 0.52^{\mathrm{a}}$ & $58.6 \pm 0.31^{\mathrm{a}}$ \\
\hline
\end{tabular}

Means within each column bearing different letter(s) are significantly different $(\mathrm{P}<0.05)$

\section{Feed intake and feed conversion ratio:}

Data of feed intake at $0-3,4-6$ and 0-6 weeks of age are listed in Table (4). Data explained that supplementing the broiler diet with marjoram leaves powder had no significant effect on feed intake during the period from 0-3 weeks of age. On the other hand, at 4-6 and 0-6 weeks of age treated groups achieved the lowest $(\mathrm{P}<0.05)$ feed intake as compared with control group. The results are in agreement with Ezz El-Arab, (2008) and Mona Osman et al. (2010) who revealed that chicks received basal diets with either levels of Rosemary, $0.5 \mathrm{~g} / \mathrm{kg}$ of Marjoram or Sweet Basil supplementation consumed the lowest $(\mathrm{P}<0.05)$ amounts comparing with that of the control.

Also, supplementing the broiler diet with marjoram leaves powder improved $(\mathrm{P}<0.05)$ feed conversion ratio during the all periods as compared with the control group. Also, supplemented groups with 1.0 and $1.5 \%$ marjoram achieved the best value of feed conversion ratio during 4-6 and 0-6 weeks of age. The results are in agreement with Ezz El-Arab, (2008) and Mona Osman et al. (2010) who stated that, broilers fed the control (un-supplemented) diet had the worst feed conversion ratio of 1.89 compared with chicks received diets of the upper level of Marjoram 1.58 being the best. However, no significant differences was observed in this regard between chicks fed diets supplemented with either Marjoram $(0.5 \mathrm{~g} / \mathrm{kg})$ of 1.60 , Sweet Basil $(0.5 \mathrm{~g} / \mathrm{kg})$ of 1.61 or Rosemary $(0.5$ or $1 \mathrm{~g} /$ $\mathrm{kg}$ ) of 1.62 and 1,63 , respectively.

As mentioned before, this may be due to the ability of marjoram to increase the efficiency of digestion by increasing digestive enzymes and saliva, calming the stomach and digestive system, improving appetite, curing or preventing basic intestinal infections and relieving diarrhea and constipation which resulting in maximizes the benefit of feed without increase in feed intake. Abaza (2001) showed that mixture of medicinal plants containing diets improved the digestibility of nutrients. 
Table (4): Averages \pm (SE) of daily feed intake (gm) and feed conversion ratio as affected by the addition of marjoram leaves powder into broiler chick diets.

\begin{tabular}{|l|c|c|c|c|c|c|}
\hline \multirow{2}{*}{ Items } & \multicolumn{3}{|c|}{ Daily feed intake (gm) } & \multicolumn{3}{c|}{ Feed conversion ratio } \\
\cline { 2 - 7 } \multicolumn{1}{r|}{ Treat. } & $\begin{array}{c}\mathbf{0 - 3} \\
\text { weeks }\end{array}$ & $\begin{array}{c}\mathbf{4 - 6} \\
\text { weeks }\end{array}$ & $\begin{array}{c}\mathbf{0}-\mathbf{6} \\
\text { weeks }\end{array}$ & $\begin{array}{c}\mathbf{0}-\mathbf{3} \\
\text { weeks }\end{array}$ & $\begin{array}{c}\mathbf{4}-\mathbf{6} \\
\text { weeks }\end{array}$ & $\begin{array}{c}\mathbf{0}-\mathbf{6} \\
\text { weeks }\end{array}$ \\
\hline $\mathbf{0}$ & $57.8 \pm 0.48$ & $150.7 \pm 0.71^{\mathrm{a}}$ & $104.3 \pm 0.31^{\mathrm{a}}$ & $1.60 \pm 0.007^{\mathrm{a}}$ & $2.10 \pm 0.005^{\mathrm{a}}$ & $1.93 \pm 0.003^{\mathrm{a}}$ \\
$\mathbf{0 . 5}$ & $57.2 \pm 0.66$ & $142.3 \pm 0.66^{\mathrm{b}}$ & $99.7 \pm 0.42^{\mathrm{b}}$ & $1.52 \pm 0.022^{\mathrm{b}}$ & $1.84 \pm 0.006^{\mathrm{b}}$ & $1.74 \pm 0.004^{\mathrm{b}}$ \\
$\mathbf{1 . 0}$ & $56.9 \pm 0.20$ & $141.6 \pm 0.68^{\mathrm{b}}$ & $99.3 \pm 0.43^{\mathrm{b}}$ & $1.50 \pm 0.013^{\mathrm{b}}$ & $1.78 \pm 0.015^{\mathrm{c}}$ & $1.69 \pm 0.015^{\mathrm{c}}$ \\
$\mathbf{1 . 5}$ & $56.9 \pm 0.23$ & $141.1 \pm 0.30^{\mathrm{b}}$ & $98.9 \pm 0.18^{\mathrm{b}}$ & $1.49 \pm 0.008^{\mathrm{b}}$ & $1.79 \pm 0.008^{\mathrm{c}}$ & $1.69 \pm 0.007^{\mathrm{c}}$ \\
\hline
\end{tabular}

Means within each column bearing different letter(s) are significantly different $(\mathrm{P}<0.05)$

\section{Physiological parameters:}

3.1. Hematocrit, hemoglobin and glucose:

Obtained data of hemoglobin content, hematocrit percentage and glucose level in Table (5) indicated that, marjoram supplementation in broiler diets did not have any effect on hemoglobin content, hematocrit percentage and glucose level at 35 and 42 days of age. The results are in agreement with Ezz El-Arab, (2008) and Mona Osman et al. (2010) stated that fed basal diets with Marjoram supplementation did not adversely affect the hemoglobin concentration, hematocrit percent and glucose concentration.

Table (5): Averages \pm (SE) of hematocrit, hemoglobin and glucose as affected by the addition of marjoram leaves powder into broiler chick diets.

\begin{tabular}{|l|l|l|l|l|l|c|}
\hline \multirow{2}{*}{ Items } & \multicolumn{2}{|c|}{ Hematocrit \% } & \multicolumn{2}{c|}{ Hemoglobin \% } & \multicolumn{2}{c|}{ Glucose (mg/ dl) } \\
\cline { 2 - 7 } Treat. & \multicolumn{1}{c|}{ 35 days } & 42 days & \multicolumn{1}{c|}{ 35 days } & \multicolumn{1}{c|}{ 42 days } & \multicolumn{1}{c|}{ 35 days } & \multicolumn{1}{|c|}{ 22 days } \\
\hline $\mathbf{0}$ & $29.0 \pm 0.58^{*}$ & $29.7 \pm 0.33$ & $8.6 \pm 0.69$ & $9.0 \pm 0.66$ & $205.1 \pm 2.32$ & $206.7 \pm 2.15$ \\
$\mathbf{0 . 5}$ & $30.7 \pm 0.67$ & $30.0 \pm 0.58$ & $9.7 \pm 0.35$ & $9.8 \pm 0.60$ & $207.8 \pm 3.81$ & $205.7 \pm 2.86$ \\
$\mathbf{1 . 0}$ & $30.0 \pm 0.58$ & $30.3 \pm 0.33$ & $9.9 \pm 0.45$ & $10.2 \pm 0.55$ & $209.5 \pm 3.74$ & $210.6 \pm 2.83$ \\
$\mathbf{1 . 5}$ & $31.3 \pm 0.67$ & $31.0 \pm 0.58$ & $10.6 \pm 0.38$ & $10.8 \pm 0.66$ & $213.9 \pm 1.65$ & $217.7 \pm 3.85$ \\
\hline
\end{tabular}

* $\mathrm{P}>0.05$

\subsection{Total protein, albumin, globulin and albumin/globulin ratio:}

Data of serum total protein, albumin, globulin and albumin/globulin ratio at 5 and 6 weeks of age are listed in Table (6). Data showed that supplementing the broiler diet with marjoram leaves powder had significant effect $(\mathrm{P}<0.05)$ on albumin, globulin and albumin/globulin ratio at 5 and 6 weeks of age being lower in treated groups than the control group in albumin and albumin/globulin. The opposite is true, marjoram supplementation in broiler diets increased significantly $(\mathrm{P}<0.05)$ globulin level in the treated groups than in the control group.

On the other hand, marjoram supplementation in broiler diets did not have any effect on total protein levels at 5 and 6 weeks of age. These results are in agreement with Ezz El-Arab, (2008) and Mona Osman et al. (2010). The significant increase in plasma globulin and significant 
decrease in both albumin and albumin/globulin may be due to the active components of the marjoram that may increase globulin level in the blood and decrease albumin and albumin/globulin. These results are in agreement with those reported by (Stroev, 1989 and Abdo Zeinab et al., 2003).

Table (6): Averages $\pm(\mathrm{SE})$ of serum total protein, albumin, globulin and albumin/globulin ratio as affected by the addition of marjoram leaves powder into broiler chick diets.

\begin{tabular}{|l|c|c|c|c|c|c|c|c|}
\hline Items & \multicolumn{2}{|c|}{$\begin{array}{c}\text { Total protein } \\
\text { (g/ dl ) }\end{array}$} & \multicolumn{2}{c|}{$\begin{array}{c}\text { Albumin } \\
\text { (g/ dl ) }\end{array}$} & \multicolumn{2}{c|}{$\begin{array}{c}\text { Globulin } \\
\text { (g/ dl ) }\end{array}$} & \multicolumn{2}{c|}{ Alb./Glob. } \\
\cline { 2 - 9 } Treat. & $\mathbf{3 5}$ days & $\mathbf{4 2}$ days & 35 days & $\mathbf{4 2}$ days & 35 days & $\mathbf{4 2}$ days & 35 days & 42 days \\
\hline $\mathbf{0}$ & $3.5 \pm 0.15$ & $3.0 \pm 0.12$ & $2.3 \pm 0.09^{\mathrm{a}}$ & $2.1 \pm 0.15^{\mathrm{a}}$ & $1.2 \pm 0.09^{\mathrm{b}}$ & $0.9 \pm 0.03^{\mathrm{b}}$ & $1.9 \pm 0.11^{\mathrm{a}}$ & $2.3 \pm 0.24^{\mathrm{a}}$ \\
$\mathbf{0 . 5}$ & $2.9 \pm 0.07$ & $2.9 \pm 0.09$ & $1.7 \pm 0.09^{\mathrm{b}}$ & $1.5 \pm 0.09^{\mathrm{b}}$ & $1.3 \pm 0.06^{\mathrm{b}}$ & $1.5 \pm 0.09 \mathrm{a}$ & $1.3 \pm 0.11^{\mathrm{b}}$ & $1.0 \pm 0.11^{\mathrm{b}}$ \\
$\mathbf{1 . 0}$ & $3.1 \pm 0.14$ & $3.1 \pm 0.14$ & $1.5 \pm 0.03^{\mathrm{b}}$ & $1.6 \pm 0.03^{\mathrm{b}}$ & $1.6 \pm 0.17^{\mathrm{ab}}$ & $1.5 \pm 0.15^{\mathrm{a}}$ & $0.9 \pm 0.13^{\mathrm{bc}}$ & $1.1 \pm 0.13^{\mathrm{b}}$ \\
$\mathbf{1 . 5}$ & $3.3 \pm 0.06$ & $3.2 \pm 0.18$ & $1.5 \pm 0.09^{\mathrm{b}}$ & $1.4 \pm 0.07^{\mathrm{b}}$ & $1.8 \pm 0.12^{\mathrm{a}}$ & $1.8 \pm 0.23^{\mathrm{a}}$ & $0.8 \pm 0.10^{\mathrm{c}}$ & $0.8 \pm 0.14^{\mathrm{b}}$ \\
\hline
\end{tabular}

Means within each column bearing different letter(s) are significantly different $(\mathrm{P}<0.05)$

\subsection{Cholesterol, LDL-cholesterol and HDL-cholesterol:}

Data of serum cholesterol, LDLcholesterol and HDL- cholesterol at 5 and 6 weeks of age are listed in Table (7). Data showed that no significant influence of experimental diets on cholesterol, LDLcholesterol and HDL- cholesterol. Ezz ElArab, (2008) obtained that adding the grounds of Rosemary, Marjoram and Sweet Basil did not significantly affect any of blood cholesterol (mg/dl), triglycerides $(\mathrm{mg} / \mathrm{dl})$, glutamic oxaloacetic transaminase (GOT) (U/L), glutamic pyruvic transaminase (GPT) (U/L), creatinine $(\mathrm{mg} / \mathrm{dl})$ and total protein $(\mathrm{g} / \mathrm{dl})$, respectively.
The insignificant effect in the present study may be due to small levels of marjoram, although most of natural feed additives such as powdered green tea flower, have inhibition effect on lipid metabolism by interfering with micelles solubilization of cholesterol in digestive tract which in turns decreased cholesterol absorption and increased the excretion of fecal bile acid cholesterol (Yang and Koo, 2000). Also, green tea like most of natural feed additives reduced pancreatic lipase activity and gastric lipase which resulted in a drastic decrease in gastric lipase that causes inhibition of digestive lipids and so likely to reduce fat digestion (Deng et al., 1998). 
Table (7): Averages \pm (SE) of serum cholesterol, LDL-cholesterol and HDL- cholesterol as affected by the addition of marjoram leaves powder into broiler chick diets.

\begin{tabular}{|c|c|c|c|c|c|c|}
\hline \multirow{2}{*}{ Treat. } & \multicolumn{2}{|c|}{ Cholesterol (mg/ dl) } & \multicolumn{2}{|c|}{ LDL (mg/ dl) } & \multicolumn{2}{|c|}{ HDL (mg/ dl) } \\
\hline & 35 days & 42 days & 35 days & 42 days & 35 days & 42 days \\
\hline $\mathbf{0}$ & $127.9 \pm 1.50^{*}$ & $128.3 \pm 0.86$ & $39.9 \pm 0.55$ & $37.9 \pm 0.58$ & $66.6 \pm 0.66$ & $74.3 \pm 1.33$ \\
\hline 0.5 & $124.6 \pm 1.76$ & $126.8 \pm 1.35$ & $38.4 \pm 0.87$ & $39.1 \pm 0.65$ & $67.6 \pm 0.56$ & $75.6 \pm 1.22$ \\
\hline 1.0 & $125.4 \pm 1.85$ & $124.9 \pm 1.09$ & $38.8 \pm 0.50$ & $37.9 \pm 0.81$ & $69.5 \pm 0.78$ & $77.9 \pm 1.09$ \\
\hline 1.5 & $124.6 \pm 2.08$ & $127.5 \pm 1.37$ & $39.6 \pm 0.33$ & $38.5 \pm 0.58$ & $68.8 \pm 0.66$ & $78.8 \pm 1.61$ \\
\hline
\end{tabular}

3.4. Monocytes (M), heterophils (H), lymphocytes $(\mathrm{L})$ and $H / L$ ratios:

Percentages of white blood cells: monocytes (M), heterophils (H), lymphocytes (L) and H/L ratios are presented in Table (8). Data explained that the differences between all treated groups and control were not significant. These results are in agreement with those reported by (El-Sherbiny et al., 1990, Abdel-Azeem,
2001, Soliman, 2003) of which, feeding broiler chickens different feed additives did not significantly affect blood constituents. While Ezz El-Arab, (2008) stated that, H/L ratio was significantly increased due to treatments of Marjoram at level $1 \mathrm{~g} / \mathrm{kg}$ diet compared with those of Sweet Basil levels and Marjoram $(0.5 \mathrm{~g} / \mathrm{kg})$ and that of the control and attributed it to enhance cellular functions due to studied feed additives supplementation.

Table (8): Averages $\pm(\mathrm{SE})$ of percentage white blood cells differentiation: monocytes $(\mathrm{M})$, heterophils $(\mathrm{H})$, lymphocytes $(\mathrm{L})$ and $\mathrm{H} / \mathrm{L}$ ratio as affected by the addition of marjoram leaves powder into broiler chick diets.

\begin{tabular}{|l|c|l|l|l|l|c|c|c|}
\hline \multirow{2}{*}{ Trems } & \multicolumn{2}{|c|}{ Lymphocytes } & \multicolumn{2}{c|}{ Heterophils } & \multicolumn{2}{c|}{ Monocytes } & \multicolumn{2}{c|}{ H/L ratio } \\
\cline { 2 - 9 } & $\mathbf{3 5}$ days & $\mathbf{4 2}$ days & $\mathbf{3 5}$ days & $\mathbf{4 2}$ days & $\mathbf{3 5}$ days & $\begin{array}{c}\mathbf{4 2} \\
\text { days }\end{array}$ & $\begin{array}{c}\mathbf{3 5} \\
\text { days }\end{array}$ & $\begin{array}{c}\mathbf{4 2} \\
\text { days }\end{array}$ \\
\hline $\mathbf{0}$ & $56.3 \pm 0.67 *$ & $60.3 \pm 0.33$ & $28.3 \pm 0.33$ & $28.7 \pm 0.33$ & $5.3 \pm 0.33$ & $4.3 \pm 0.33$ & $0.50 \pm 0.006$ & $0.48 \pm 0.005$ \\
$\mathbf{0 . 5}$ & $57.3 \pm 0.33$ & $61.0 \pm 0.58$ & $29.3 \pm 0.33$ & $29.3 \pm 0.88$ & $5.7 \pm 0.33$ & $5.0 \pm 0.58$ & $0.51 \pm 0.003$ & $0.48 \pm 0.016$ \\
$\mathbf{1 . 0}$ & $57.3 \pm 0.33$ & $62.0 \pm 0.58$ & $30.3 \pm 0.67$ & $30.3 \pm 0.67$ & $4.7 \pm 0.33$ & $4.7 \pm 0.33$ & $0.53 \pm 0.010$ & $0.49 \pm 0.015$ \\
$\mathbf{1 . 5}$ & $58.3 \pm 0.33$ & $62.3 \pm 0.33$ & $29.7 \pm 0.33$ & $31.3 \pm 0.67$ & $6.0 \pm 0.58$ & $5.7 \pm 0.33$ & $0.51 \pm 0.009$ & $0.50 \pm 0.013$ \\
\hline
\end{tabular}

$* \mathrm{P}>0.05$ 


\subsection{Haemagglutinin antibody (Ab) titers, spleen and bursa percentages:}

Averages of serum haemagglutinin antibody $(\mathrm{Ab})$ titers at 6 weeks of age, spleen and bursa percentages are listed in Table (9). Data elucidated that, treatment with marjoram did not show any significant effect on Ab. titers at 6 weeks of age, spleen percentage and bursa percentage. The results of the present study are in contrast to Ezz El-Arab, (2008) who stated that, feeding experimental diets inclusive either Rosemary, Marjoram or Sweet Basil improved the immune status as reflected by ELISA titer compared with that of the control and attributed the improvement of antibody level against Newcastle disease virus (NDV) may be due to the higher mineral contents of Marjoram, and this might affect the oxygen transportation that is needed for eventually increasing hemoglobin synthesis in the blood (Jones and Bark, 1979). Toghyani et al. (2011) used thyme powder $5 \mathrm{~g} / \mathrm{kg}$ diets and did not find any significant differences of NDV antibody titers compared to the control. Moreover, Toghyani et al.,(2010) did not find any effect of ginger and thyme on the relative weight of bursa and spleen in the broiler chicks.

Table (9): Averages \pm (SE) of spleen percentage, bursa percentage and haemagglutinin antibody (Ab) titers against (SRBC's) as affected by the addition of marjoram leaves powder into broiler chick diets.

\begin{tabular}{|l|l|l|l|}
\hline \multicolumn{1}{|c|}{ Treat } & \multicolumn{1}{|c|}{ Ab. } & \multicolumn{1}{c|}{ Spleen\% } & \multicolumn{1}{c|}{ Bursa\% } \\
\hline $\mathbf{0}$ & $5.1 \pm 0.35^{*}$ & $0.21 \pm 0.013$ & $0.15 \pm 0.009$ \\
$\mathbf{0 . 5}$ & $6.2 \pm 0.18$ & $0.20 \pm 0.013$ & $0.15 \pm 0.008$ \\
$\mathbf{1 . 0}$ & $5.8 \pm 0.30$ & $0.19 \pm 0.006$ & $0.16 \pm 0.008$ \\
$\mathbf{1 . 5}$ & $6.0 \pm 0.44$ & $0.20 \pm 0.007$ & $0.16 \pm 0.005$ \\
\hline
\end{tabular}

\section{CONCLUSION}

Considering the results of the current study it could be concluded that supplementation of marjoram powder, particularly the higher levels (1.0 and $1.5 \%)$ in broiler diets has the potential to improve productive performance like a growth promoters but without any detrimental impacts on immune responses and blood parameters of the birds. 


\section{REFERENCES}

Abaza, I. M. K., (2001). The use of some medical plants as feed additives in broiler diets. Ph.D. Thesis, Faculty of Agriculture, Alexandria University, Egypt.

Abdel-Azeem, F.; Faten, A.A. Ibrahim and Nematallah, G.M.Ali (2001). Growth performance and some blood parameters of growing Japanese quail as influenced by dietary different protein levels and microbial probiotic supplementation. Egypt. Poult. Sci. 21: 465-489.

Abdo, Zeinab M.A.; Soliman, A.Z.M. and Barakat, Olfat S. (2003). Effect of hot pepper and marjoram as feed additives on the growth performance and the microbial population of the gastrointestinal tract of broilers. Egypt. Poult. Sci. 23 (I): 91-113.

Assmann, G, H.V. Jabs, U. Kohnert, W. Nolte and $H$. Schriewer, (1984).LDL-cholesterol polyvinyl sulphate method (kit of LDL) Clin. Chem. Acta., 140:77-83.

Banchio, E., P.C. Bogino, J. Zygadlo, W. Giordano, (2008). Plant growth promoting rhizobacteria improve growth and essential oil yield in Origanum majorana L. Biochem. Syst. Ecol., 36: 766-771.

Ben, H. E. N., M. M. Abdelkefi, R. B. Aissa and M. M. Chabouni, (2001). Antibacterial screening of Origanum majorana L. oil from Tunisia. J. Ess. Oil Res., 13: 295297.

Botsoglou, N.A., Christaki, E., FlorouPaneri, P., Gieannenas, I., Papageorgiou, G. and Spais, A.B., (2004). The effect of a mixture of herbal essential oils or $\alpha$-tocopheryl acetate on performance parameters and oxidation of body lipid in broilers. S. Afr. J. Anim. Sci. 34: 52-61.

Coles E. H. (1986). Veterinary clinical pathology. 4th Ed. W. B. Saunders company Philadelphia , London. Toronto.

Cowan, M.M.;(1999). Plant products as antimicrobial agents Clinical Microbiology Reviews, 12 (4): 564582.

Cross, D.E., Svoboda, K., McDevitt, R.M. and Acamovic, T., (2003). The performance of chickens fed diets with and without thyme oil and enzymes. Br. Poult. Sci. 44 (1): 18-19.

Deng, Z.Y.; Teo, B.Y.; Li, X.L.; He, J.M.; Cheni, Y.F. and Chu, F. (1998). Effect of tea on blood glucose, blood lipid and antioxidants acyivity in old rats. J. of tea- Sci. 18: 1, 74-77.

Dorman, H. J. D. and S. G. Deans, (2000). Antimicrobial agents from plants: antimicrobial activity of plant volatile oils. Journal of Applied Microbiology. 88: 308-316.

Doumas B., (1971). Colorimetric determination of serum albumin. Clin.Chem.Acta. 31: 400-403.

Duncan, D. B., (1955). Multiple ranges and multiple F-test. Biometric, 11: 1042.

El-Sherbiny, A. E.; S. H. El-Samra; M. Raafat, and K. Y. Nagmy, (1990). Antibiotics as growth promoters in broiler: 1- Effect of flavomycin or zinc bacitracin supplements on performance of broiler chicks fed diets varying in energy and protein content. J. Agric. Sci. Mansoura Univ. 15:384-398.

Ezz El-Arab, W. F. (2008). Productive, physiological, immunological and economical effects of supplementing natural feed additives to broiler diets. M. Sc. 
Thesis Faculty of Agriculture, Alexandria University, Egypt.

Farooqi, A. A. and B. S. Sreeramu, (2004). Cultivation of medicinal and aromatic crops. Universities Press, India. pp. 465-470.

Gill, C., (1999). Herbs and plant extracts as growth enhancers. Feed Int. 20 (4): 20-23.

Hallnet

Ltd, (2014). http://www.herbwisdom.com/herbmarjoram.html

Humphrey, B. D., N. Huang and Klasing, K.C., (2002). Rice expressing lactoferrin and lysozyme has antibiotic-like properties when fed to chick. J. Nutr. 132: 1214-1218.

Jones E. A., and P. D. Bark (1979). Chemical Diagnosis of disease. Brown, S. S., F. L. Mitchell and D. S. Young (Eds), elsevier, Biomedical Press, Amsterdam, New York, Oxford, P: 325-363.

Kamel, C., (2001). Tracing modes of action and the roles of plant extracts in non-ruminants. In: Recent Advances in Animal Nutrition. Eds. Garnsworthy, P.C. and Wiseman, J., Nottingham University Press, Nottingham, UK. pp. 135-150.

Kirtikar, K. R. and B. D. Basu, (1985). Indian medicinal plants. (Eds.: E. Blatter, J.F. Caius and S.K. Mhaskar). Bishen Singh and Mahendra Pal Sing, Dehradun. 3: 250.

Langhout, P., (2000). New additives for broiler chickens. World PoultryElsevier, 16 (3): 22-27.

Leeja, L. and J. E. Thoppil, (2007). Antimicrobial activity of methanol extract of Origanum majorana L. (Sweet marjoram). Journal of Environmental Biology, 28(1): 145146.

Lewis, M. R., S. P. Rose, A. M. Mackenzie and L. A. Tucker, (2003). Effects of dietary inclusion of plant extracts on the growth performance of male broiler chickens. Br. Poult. Sci. 44 (1): 43 44.

Mona Osman, H. M. Yakout, H. F. Motawe and W. F. Ezz El-Arab, (2010). Productive, physiological, immunological and economical effects of supplementing natural feed additives to broiler diets. egypt. poult. sci. 30 (1): 25-53

National Research Council, NRC, (1998). Nutrient Requirements of Poultry, 10th ed. Washington, DC, National Academy Press.

Sturkie, P.D, (1986). " Avian Physiology". by P.D. Sturkie, 4th ed., SpringerVerlag, New York. INC.

Sarica, S., A. Ciftci, E. Demir, K. Kilinc and Y. Yildirim, (2005). Use of an antibiotic growth promoter and two herbal natural feed additives with and without exogenous enzymes in wheat based broiler diets. South African Journal of Animal Science 35 (1): 61-72.

SAS, (1996). SAS User's Guide, statistics (6.2th Ed.) Cary NC: SAS Institute Inc.

Soliman, A. Z. M.; M. A. Ali and M. A. Abdo Zeinab, (2003). Effect of marjoram, bacitracin active yeast as feed additives on the performance and the microbial content of the broiler's intestinal tract. Egypt. Poult. Sci 23 (3): 445-467.

Stroev E. A., (1989). Biochemistry Text Book, MIR Publishers, MOSCOW.

Tietz N. W., (1982). Fundamental of Clinical Chemistry. Edition by Norbert Sanrders Company, Philadelphia, USA.

Toghyani, M., M. Tohidi, A. A. Gheisari and S. A. Tabeidian (2010). Performance, immunity, serum biochemical and hematological parameters in broiler chicks fed dietary thyme as alternative for an antibiotic growth promoter. African 
Journal of Biotechnology. 9 (40): 6819-6825.

Toghyani, M., M. Toghyani, M. Mohammadrezaei, S. A. Tabeidian and G. Ghalamkari (2011). Effect of cocoa and thyme powder alone or in combination on humoral immunity and serum biochemical metabolites of broiler chicks. International Proceedings of Chemical, Biological \& Environmental Engineering. 22: 114 $-118$.

Triantaphyhou, K.; G. Blekas and D. Boskou, (2001). Anti-oxidative properties of water extracts obtained from herbs of the spices Lamiaceae. International journal of food sciences and nutrition 52 (4): 313317.

Tucker, L. A., (2002). Plant extracts to maintain poultry performance. Feed Int. 23 (9): 26-29.

Van der Zijpp, A. J. and F. R. Leenstra, (1980). Genetic analysis of the humoral immune response of White Leghorn chickens. Poult. Sci., 59: 1363-1369.
Warnick (1983): HDL - cholesterol procedure No OSSgg (kit of HDL cholesterol) selection methods Clin. Chem., 10: 91 - 99.

Watson M., (1960). A method for determination of cholesterol. Clin. Bioch. 58(4): 379-382.

Wenk, C., (2000). Why all the discussion about herbs? Proc. Alltech's 16th Ann. Symp. Biotechnol. in the Feed Industry. Ed. Lyons, T.P., Alltech Tech. Publ., Nottingham, University Press, Nicholasville, KY. : 79-96.

Winderobe M. M., (1967). Clinical Hematology. 6th Ed. pp., 414419.Lea and Febiger, Philadelphia, USA.

Witt L., and C. Trendelenburg, (1982). A method for rapid determenation of total protein of serum, J. P. Clin., Biochem., 220-235.

Yang, T. T. C. and M. W. L. Koo, (2000). Chinese green tea lowers cholesterol level through an increase in fecal lipid excretion. Life Sci. 66 (5): 477-423. 


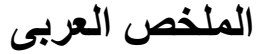 \\ الاداء الانتاجى والاستجابة المناعية لكتاكيث التسمين تحت تاثير استخدام علائق اوراق البردقوش المري المطحونة
}

\author{
عبدالله حسن حسبن على الزئ \\ قسم الاتتاج الحبوانى والدواجن ـ كلبة الزراعة حسن - جامعة جنوب الولادى ـ قنا - مصر
}

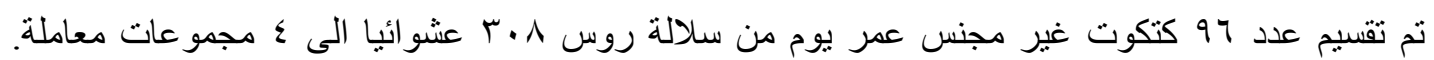

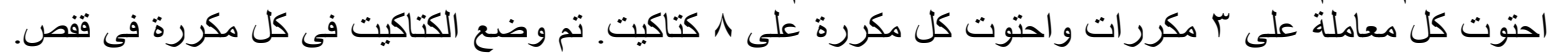

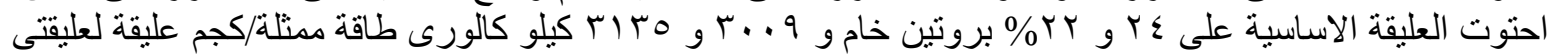

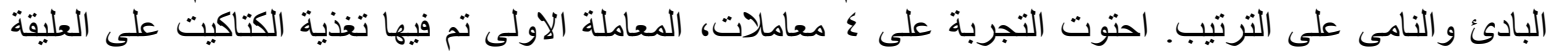

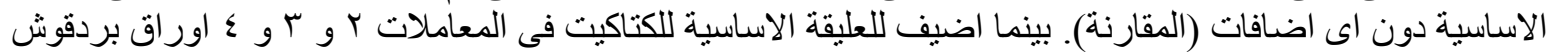

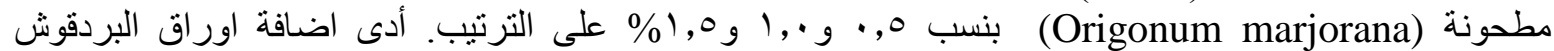

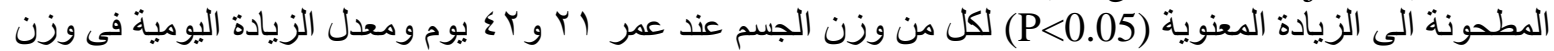

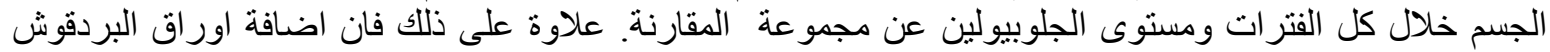

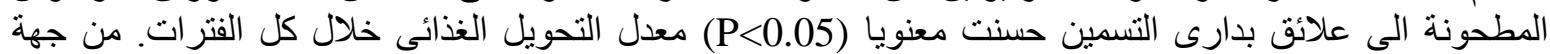

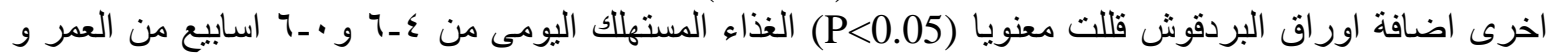

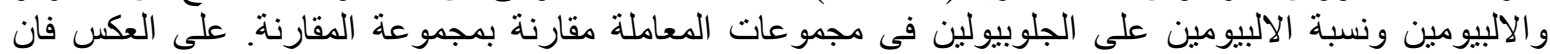

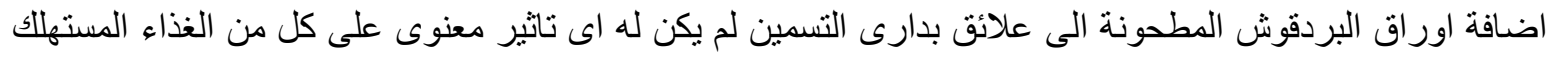

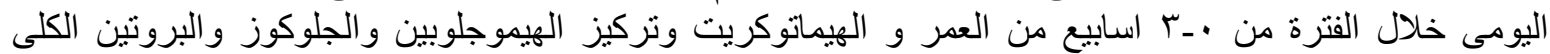

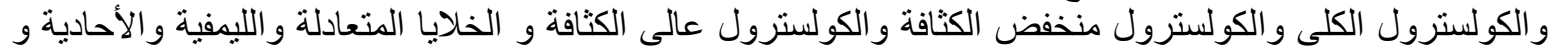

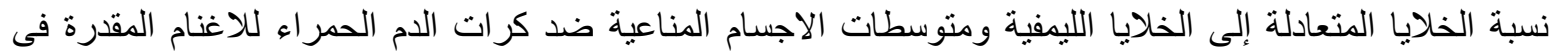

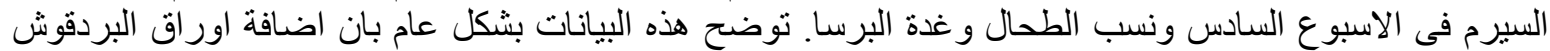

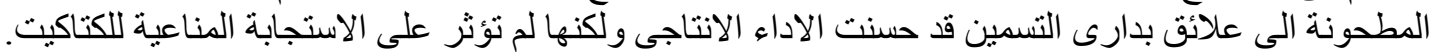

